\title{
EXPANSION OF THE GENOTYPIC VARIABILITY IN WATERMELON BY PHYSICAL MUTAGENESIS
}

\author{
Shabetia $^{1}$ O.N., Serhienko ${ }^{2}$ O.V., Mohilnaia ${ }^{2}$ E.N., Kondratenko² S.I., Morhun ${ }^{3}$ L.V. \\ ${ }^{1}$ Plant Production Institute named V.Ya Yuriev of NAAS, Ukraine \\ ${ }^{2}$ Institute of Vegetable and Melon Growing of National Academy of Agrarian Sciences of Ukraine, \\ Ukraine \\ ${ }^{3}$ Presidium of the National Academy of Agrarian Sciences of Ukraine, Ukraina
}

Studies have been conducted on 18 promising watermelon genotypes to expand the genotypic variability of watermelon by induced mutagenesis. Air-dried seeds were irradiated with a closed ${ }^{60} \mathrm{Co} \gamma$-source «Doslidnyk» (Department of Molecular and Medical Biophysics, Faculty of Radiophysics, Biomedical Electronics and Computer Systems, V.N. Karazin Kharkiv National University of MES of Ukraine). The patterns of influence of the irradiation doses on plant growth and development have been determined, both in individual genotypes and for the whole sample. Sources of economically valuable traits have been identified.

Key words: watermelon; genotype; trait; induced mutagenesis; $\gamma$-irradiation; doses of $\gamma$ irradiation; cluster; patterns.

Introduction. Experimental mutagenesis [1,2], along with the global gene pool of crops, is a source of hereditary variation. Experimental mutation production is an effective way to boost breeding capacity. Artificially induced mutations can be used as an improved variety for industrial cultivation, as a material for hybridization with carriers of other mutations and varieties to produce new improved varieties and heterotic $\mathrm{F}_{1}$ hybrids, and as a source of additional variability in hybrid offspring [3]. Mutations are one of the main sources of hereditary variation. To use mutagens, one should select the most valuable varieties, in which particular, important for breeding traits are to be induced [4]. Seeds are exposed to physical ( $\gamma$-irradiation or fast neutrons) and chemical (ethyleneimine, nitrosomethylurea, nitrosoethylurea) mutagens. The use of mutagens in watermelon allows obtaining mutants with a short growing period, short determinant stems, compact arrangement of fruits, large fruits, increased yields, predominantly female flowers, high content of dry matter in fruits, increased resistance to diseases, small numbers of seeds in fruits $[5,6,7,8]$. Mutants are a source of new traits that need to be transmitted to cultivated varieties. Mutants with non-parted leaves, changes in fruit pigmentation and patterns, pulp color, size and color of seeds are more common [9].

Purpose. Our purpose was to analyze the possibility of using induced mutagenesis and mutant genes for the development of fundamentally new approaches to solving current breeding problems in enriching the genetic variability of the crop, expanding the level and range of the morphobiological potential of modern watermelon genotypes in relation to their suitability for mechanized production, resistance to diseases, increased contents of biologically valuable compounds in fruits, marketable appearance, high preservation capacity and transportability.

Materials and methods. To expand the genotypic variability in watermelon, physical mutagenesis was used. Eighteen breeding watermelon accessions exposed to gamma rays were studied. Air-dried seeds were irradiated with a closed ${ }^{60} \mathrm{Co} \gamma$-source «Doslidnyk» (Department of Molecular and Medical Biophysics, Faculty of Radiophysics, Biomedical Electronics and Computer Systems, V.N. Karazin Kharkiv National University of MES of Ukraine). Irradiation doses of 150, 200 and 250 Gy were investigated. Control specimens were not irradiated. The plot area was 19.6 $\mathrm{m}^{2}$, performed in singlicate. Seeds were irradiated 3 days before sowing. The study was conducted for 3 years.

(c) O.N. Shabetia, O.V. Serhienko, E.N. Mohilnaia, S.I. Kondratenko, L.V. Morhun. 2021. ISSN 1026-9959. Селекція і насінництво. 2021. Випуск 119. 
Results and discussion. The breeding accessions were evaluated for their morphological and biological characteristics. Careful screening of the breeding accessions for the morphological features of plants and fruits revealed morphobiological changes in plants and their organs. The results show that some plants were affected by the mutagen, and the exposed specimens had various morphological changes.

At the initial stage of morphogenesis - vining - plants with an increased number of nodes were seen. During the stem formation, the stem fasciation followed by stem bifurcation was observed, In the seed setting phase, plants with shortened internodes and paired arrangement of primordiums in alternate nodes, as well as 2 primordiums per node, were noted. A spontaneous mutation - fringed leaves in line 46 - was also noted. No severe morphoses in fruit color were observed during the genotype screening in the biological maturity phase.

The most informative economic useful features in breeding for increased levels of economically valuable traits are yield, marketability, average weight of marketable fruit, the growing period length, order of the $1^{\text {st }}$ female flower formation, the "seedlings - to female flowering" period, the "female flowering - maturation" period, and the stem length.

Each of these features was statistically analyzed for its expression patterns and levels in each of the 18 genotypes, depending on the variants of exposure to the mutagen (different doses of $\gamma$ irradiation - $150 \mathrm{~Gy}, 200 \mathrm{~Gy}$ and $250 \mathrm{~Gy}$ ). The analysis revealed the different genotypes had different responses to the mutagenic factor. The patterns in influence of some irradiation doses on the plant growth and development have been established both for individual genotypes and for the entire sample.

The average number of clusters is the most informative for all the traits. We have determined that their most appropriate number was 5 , as clear patterns were observed with 5 clusters.

Based on the results, the sample of the lines and variants was divided into separate groups (clusters) according to the expression levels of economically valuable features.

The figures illustrate the effect of gamma-irradiation on the expression of a particular feature with grouping (clusterization) of the accessions in comparison with the control. The clusterizattion of the breeding accessions by yield compared to the control is shown in Figure 1.

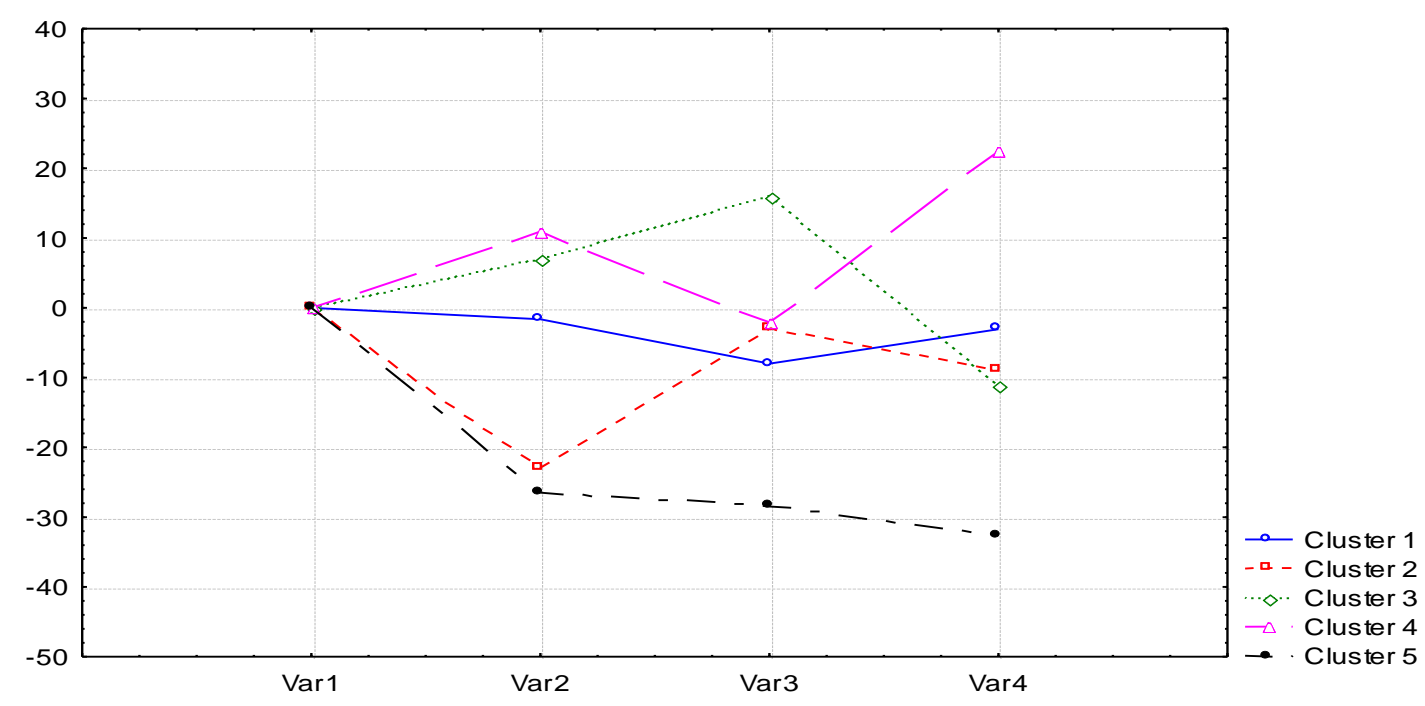

Fig. 1 Clusterization of the genotypes by yield

Note: 1 - control; 2 - 150 Gy; 3 - 200 Gy; 4 - 250 Gy.

Cluster 5 contained the greatest number of genotypes (33.3\%), which gave decreased yields in comparison with the control. The most dramatic decrease in the yield occurred after 150 Gy irradiation in genotypes $\mathrm{K} 107612 / 230$, K 105468/234, K 107345/242, K 106806/246, K $107352 / 270$, and K $104939 / 282$. The following results are useful for breeding practice: an increase in the yield after 150 Gy irradiation and a sharp increase in the yield after 250 Gy irradiation in cluster 4 genotypes (K 107348/226, K SEL2/238, K 104937/274, K 107342/278 [22.2\%]); cluster 3 
showed a gradual increase in the yield after 150 Gy or 200 Gy irradiation and a sharp decrease after 250 Gy in genotypes K 107350/222 and K 104930/294.

The genotype clusterization by marketability is shown in Figure 2. Cluster 2 included the greatest number of genotypes (38.9\%), which gave slightly increased yields after 150 Gy, slightly decreased yields after 200 Gy in comparison with the control, and showed a slight upward trend in the yield after $250 \mathrm{~Gy}$ in comparison with the control (genotypes K 107612/230, K SESHar/262, K 107352/270, K 107342/278, K 104937/274, K 104939/282, K 104346/298) (Fig. 2).

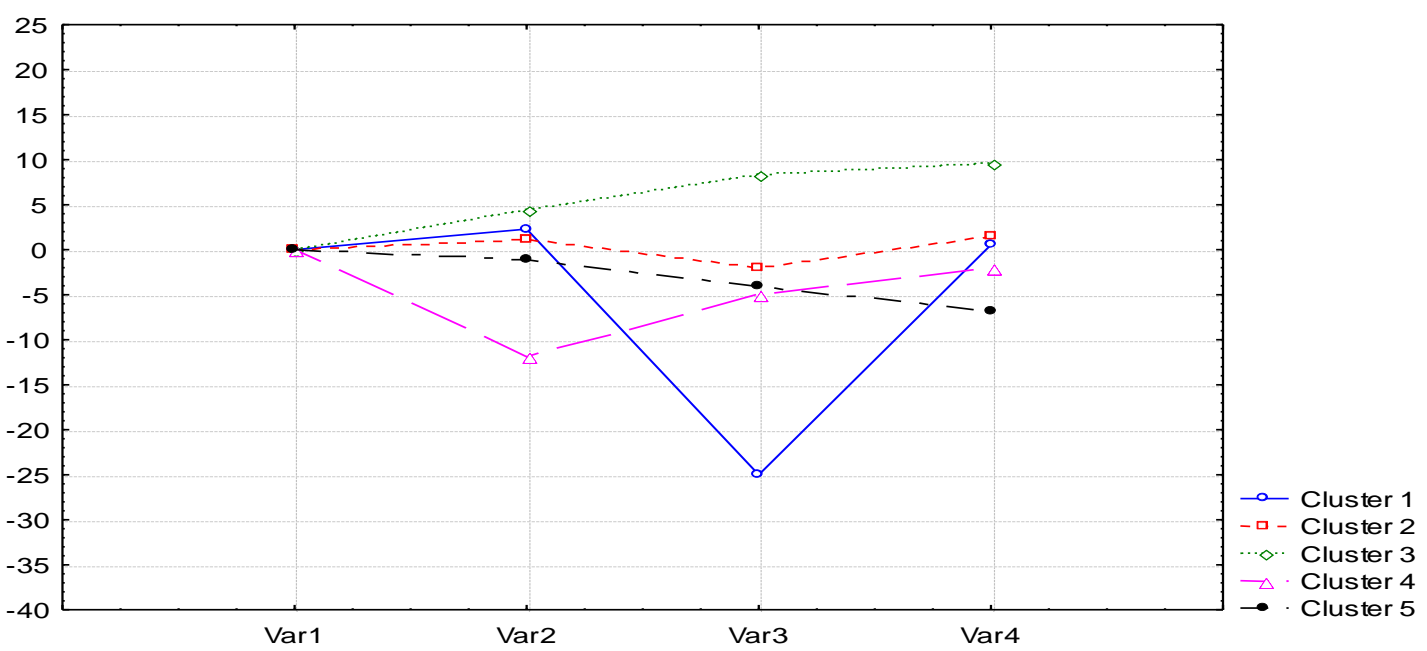

Fig. 2 Clusterization of the genotypes by marketability

The gradual increase in marketability after 150 Gy to 250 Gy in cluster 3 genotypes ( $\mathrm{K}$ $107350 / 222$ and $\mathrm{K} \mathrm{107348/226} \mathrm{[11.1 \% ])} \mathrm{compared} \mathrm{to} \mathrm{the} \mathrm{control} \mathrm{is} \mathrm{useful} \mathrm{for} \mathrm{breeding} \mathrm{practice.}$

The genotype clusterization by the average weight of marketable fruit is shown in Figure 3.

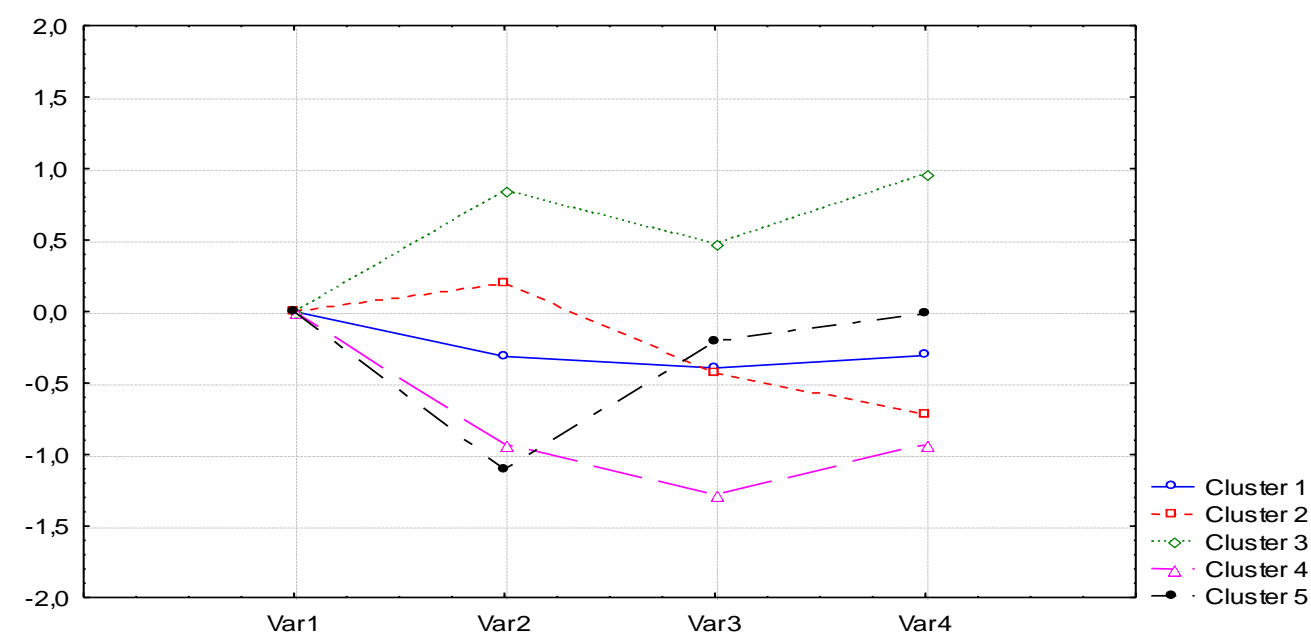

Fig. 3 Clusterization of the genotypes by the average weight of marketable fruit

Cluster 2 contained the greatest number of genotypes (38.9\%), which were characterized by an increase in the average weight of marketable fruit after $150 \mathrm{~Gy}$ and a decrease in the average weight after $200 \mathrm{~Gy}$ and $250 \mathrm{~Gy}$ related to the control (genotypes K 107350/222, K 107612/230, K $104939 / 282$, K 104930/294, K 104346/298). A significant increase in the average weight of marketable fruit after exposure 2 related to the control, a slight decrease in the average weight after $200 \mathrm{~Gy}$, and again a significant increase after $250 \mathrm{~Gy}$ irradiation in comparison with the control in cluster 3 genotypes (K 107348/226, K SEL2/238, K 104945/250 [16.7\%]) are useful for breeding practice. Other genotypes showed a decrease in the in the average weight of marketable fruit compared to the control. Only in cluster 5 genotypes, the average weight of marketable fruit after 250 Gy did not differ from the control value. 
The clusterization of the genotypes by the "seedlings - maturation" period length is shown in Figure 4.

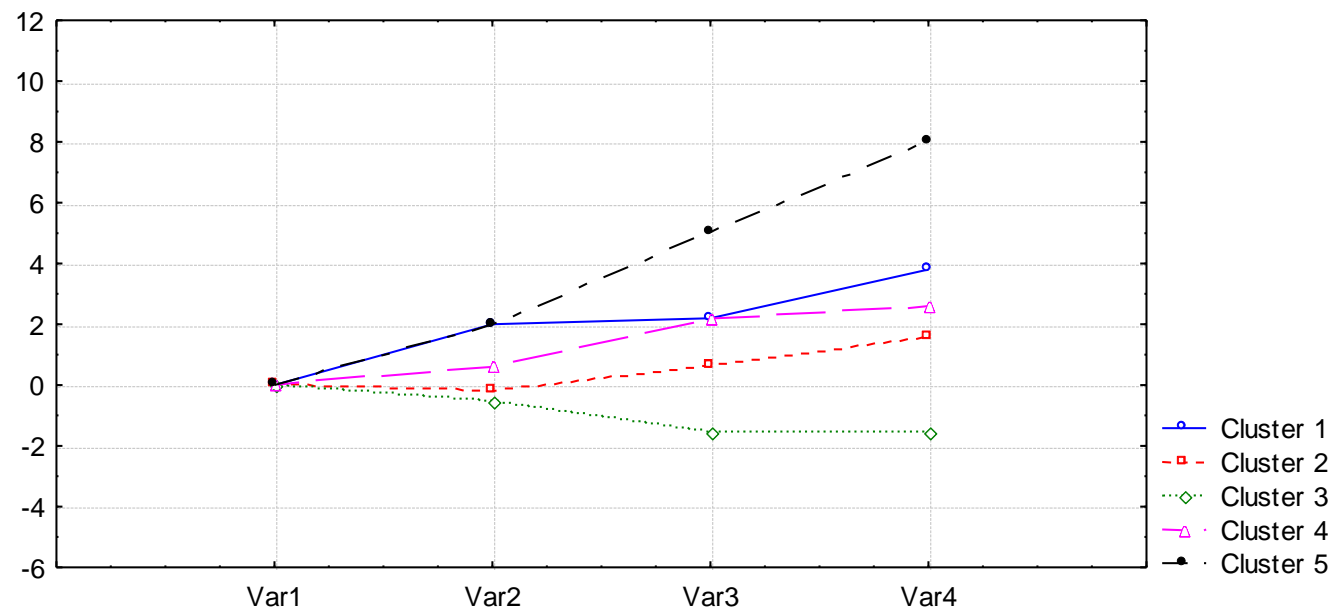

Fig. 4. Clusterization of the genotypes by the the "seedlings - maturation" period length

Growing period clusters 1, 2, and 4 had the greatest numbers of genotypes (27.8\%), and they all gave increased (to a various degree) yields in comparison with the control. The longest growing period was recorded in a cluster 5 genotype (K 106806/246) irradiated at 150, 200 or 250 Gy.

A significant shortening in the growing period in cluster 3 genotypes irradiated at 150,200 or 250 Gy related to the control is useful for breeding practice. The shortest growing period was observed in accessions K SESHar/262 and K 107342/278 (11.1\%) after 200 and 250 Gy.

The clusterization of the genotypes according to the order of the $1^{\text {st }}$ female flower formation is shown in Figure 5.

Cluster 2 had the greatest number of genotypes (38.9\%) and included genotypes $\mathrm{K}$ 107350/222, K 107345/242, K 104945/250, K SEMak/258, K SESHar/262, K 104939/282, K $104415 / 290$, which tended to increase the ordinal number of the $1^{\text {st }}$ female flower formation after $200 \mathrm{~Gy}$ and to decrease it after $250 \mathrm{~Gy}$. The expression of this feature had peculiarities in the following cluster 5 accessions (27.8\%): K 107348/226, K 107612/230, K SEL2/238, K 104937/274, K 105206/286, which had decreased ordinal numbers of the $1^{\text {st }}$ female flower formation after exposures 2 and 3 related to the control, but this feature was hardly different from the control after 250 Gy (exposure 4). These findings should be used in breeding for early maturation, while genotypes after exposures 2 and 3 can be used in subsequent work as possible sources of early maturation.

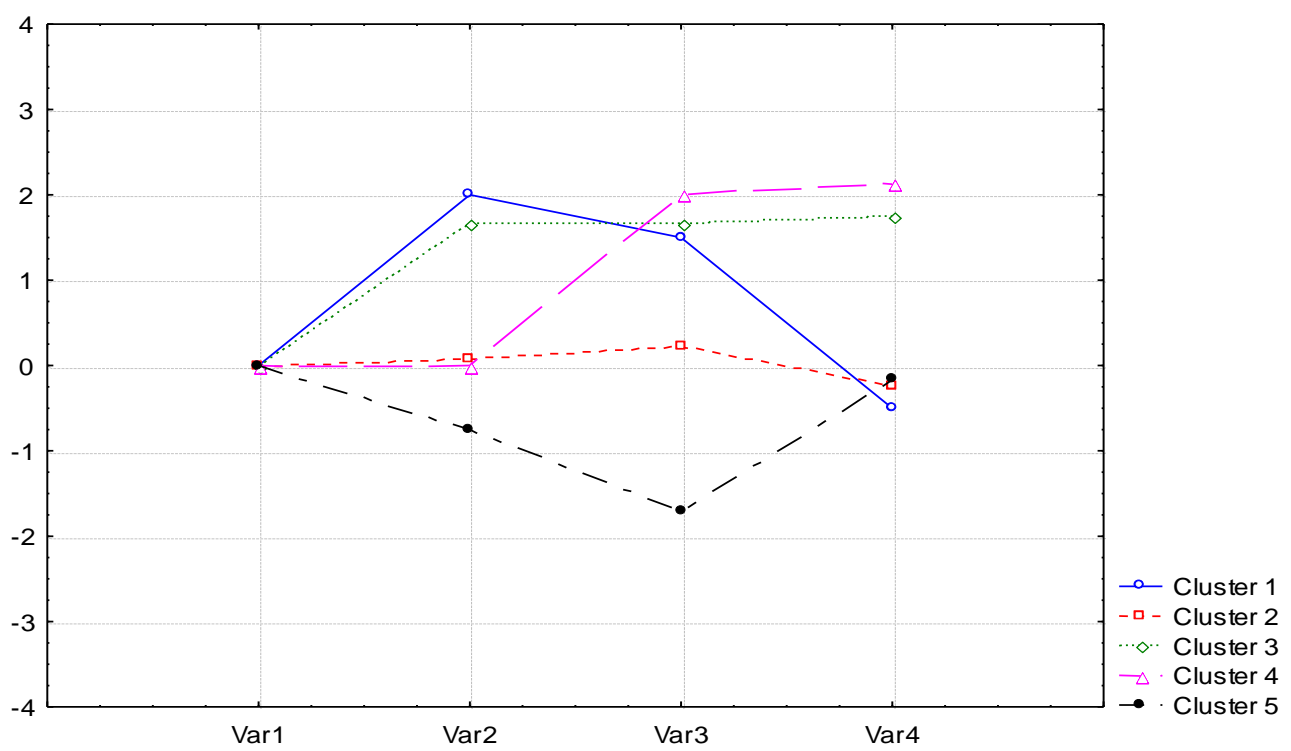

Fig. 5. Clusterization of the genotypes according to the order of the $1^{\text {st }}$ female flower formation 
Figure 6 shows the clusterization of the genotypes by the "seedlings - female flowering" period length.

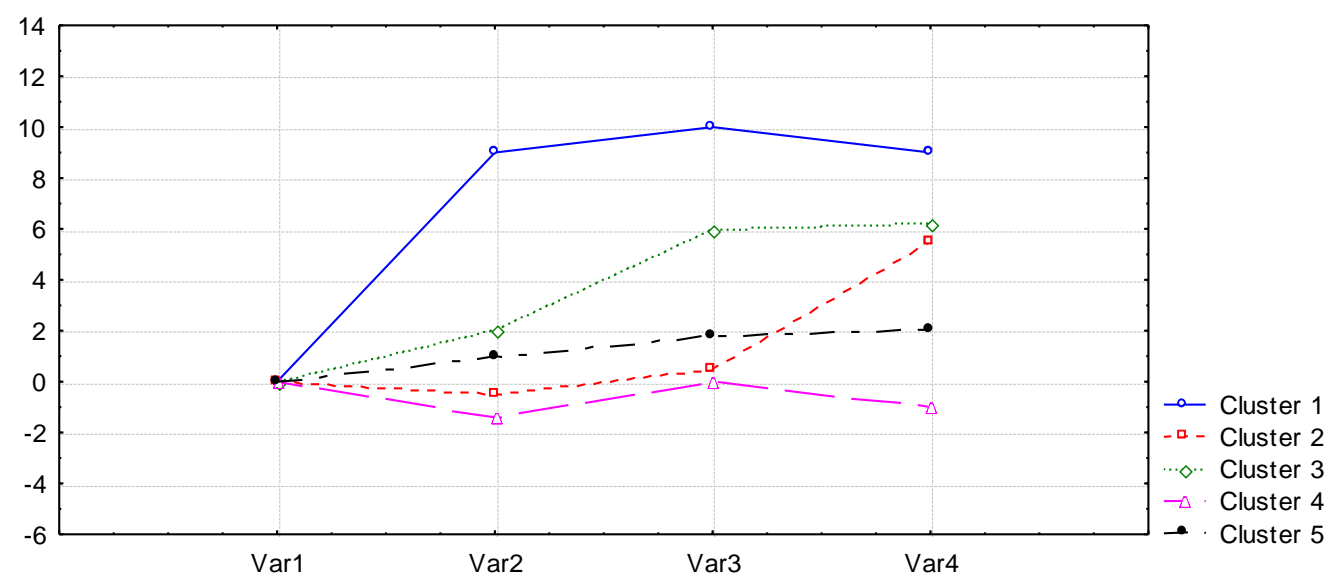

Fig. 6. Clusterization of the genotypes by the "seedlings - female flowering" period length

As to this feature, the genotype clusterization was as follows: clusters $2(22.2 \%), 3(22.2 \%)$, $5(22.2 \%)$ and $4(27.8 \%)$ contained the greatest numbers of genotypes; all of them had more days from mass germination to female flowering than in the control, which extended their growing periods. The highest level of this feature was observed in cluster 1 genotype (K SESHar/262) after $200 \mathrm{~Gy}$, but the growing period in this genotype was the shortest. There was also a slight reduction in this period in cluster 4 genotypes (K 107348/226, K 107612/230, K 105468/234, K 105415/290, K 104930/294) after exposures 2 and 4.

As to the "female flowering-maturation" period, the genotype clusterization was as follows: clusters 3 and 4 included the greatest number of genotypes (33.3\%). Cluster 3 genotypes (K 104945/250, K SE Mak/258, K 104937/274, K 107342/278, K 104939/282, K 105206/286) had fewer days from mass female flowering to mass maturation of fruits after 250 Gy irradiation, while in cluster 4 genotypes (K 107350/222, K 107348/226, K 105468/234, K SEL2/238, K 105415/290, $\mathrm{K} 104930 / 294)$ this period extended after exposure 4 (250 Gy). A significantly reduction in this period in cluster 2 genotype 262 after $200 \mathrm{~Gy}$ or $250 \mathrm{~Gy}$ is useful for breeding practice, and the expression levels of this feature in these variants were identical.

The stem length was measured 2 twice during the growing period. The first measurement was made during the female flowering phase of the genotype population in order to determine the effect of irradiation during the initial grow on the plant growth and development.

The genotype clusterization by the stem length during the female flowering phase was assessed. Clusters 1 (27.8\%), $3(27.8 \%)$ and $4(22.2 \%)$ included the greatest numbers of genotypes. All the genotypes of these groups had inhibited (to a various degree) growth and development during this phase. The growth in cluster 2 genotype K 107346/298 was drastically inhibited after $200 \mathrm{~Gy}$, however, almost normal after $250 \mathrm{~Gy}$ related to the control. Therefore, 200 Gy irradiation of genotype K 107346/298 is effective in breeding for short stems. A significant elongation of the stem in cluster 5 genotypes irradiated at $200 \mathrm{~Gy}$ is interesting for breeding practice. These are genotypes K 107350/222, K 107348/226, and K 107612/230.

At the same time, the clusterization of the genotypes by the stem length at the end of the growing period was as follows: clusters $1(27.8 \%), 3(27.8 \%)$ and $4(22.2 \%)$ included the greatest numbers of genotypes. All the genotypes of these groups had inhibited (to a various degree) growth and development during this phase.

The possibility of cluster 1 genotype K 106806/246 -based breeding for short stems with gamma irradiation at 150, 200, and $250 \mathrm{~Gy}$ was evaluated for breeding practice. In breeding for long stems, it is advisable to use doses of $200 \mathrm{~Gy}$ and $250 \mathrm{~Gy}$ on cluster 3 genotypes K 107350/222, $\mathrm{K} 107352 / 270$, and $\mathrm{K} 104930 / 294$, as well as doses of 150,200 , and especially 250 Gy on cluster 5 genotypes K SEL2/238, K 104945/250, K SEMak/258, K 104937/274, K 107342/278, K 
$105206 / 286$, and K 105415/290. Genotype K 107350/222 was proven to be a possible source of a long stem, since the espression of this feature was stable both in the female flowering phase and at the end of the growing period.

Conclusions. The study results show that $\gamma$-irradiation had a depressing effect on the majority of genotypes (late maturation, long or short stems, altered order of the $1^{\text {st }}$ female flower formation, extended phases of the growing period), however, as we noted above, both individual genotypes and separate groups (clusters) of them, in which expression of traits is opposite (alternative), have been identified. Due to this, the peculiarities of the trait expression were revealed; the patterns of practical use of gamma irradiation in breeding programs were defined to expand the genotypic variability range; and $\mathrm{M}_{1-3}$ accessions were selected for use in breeding to improve breeding features.

Basing on the experimental data, we recommend using the identified sources of economically valuable features in breeding with subsequent evaluating the trait expression stability in the following generations:

- In breeding for yield capacity: $250 \mathrm{~Gy}$; cluster 4 genotypes K 107348/226, K SEL2/238, K 104937/274, and K 107342/278;

- In breeding for marketability: 150-250 Gy; cluster 3 genotypes K 107350/222 and K 107348/226;

- In breeding for large fruits: 150, 200, and $250 \mathrm{~Gy}$; cluster 3 genotypes K 107348/226, K SEL2/238, and K 104945/250;

- In breeding for late maturation: 150, 200, and 250 Gy; cluster 5 genotype K 106806/246;

- In breeding for early maturation: 200 and $250 \mathrm{~Gy}$; cluster 3 genotypes K SESHar/262, and K 107342/278 as well as 150 and 200 Gy; cluster 5 genotypes K 107348/226, K 107612/230, K SEL2/238, K 104937/274, and K 105206/286;

- In breeding for long stems: 200 and 250 Gy; cluster 3 genotypes K 107350/222, K $107352 / 270$, and K 104930/294; 150, 200, and especially 250 Gy; cluster 5 genotypes K SEL2/238, K 104945/250, K SEMak/258, K 104937/274, K 107342/278, K 105206/286, and K 105415/290;

- In breeding for short stems: 150, 200, and $250 \mathrm{~Gy}$; cluster 1 genotype K 106806/246.

\section{Список використаних джерел}

1. Теодорадзе С.Г. Создание новых сортов сельскохозяйственных культур интенсивного типа методом радиационной селекции. Сельскохозяйственная биология. 1983. № 10. С. $62-67$.

2. Моргун В.В. Спонтанна та індукована мутаційна мінливість і її використання в селекції рослин. Генетика і селекція в Україні на межі тисячоліть. 2001. Т. 2. С. 144-174.

3. Кравченко В.А., Корнієнко С.І., Кондратенко С.І., Сергієнко О.В., Горова Т.К., Самовол О.П., Сайко О.Ю. Ефективні методи та способи селекції і насінництва овочевих і баштанних рослин. Вісник аграрної науки. 2017. № 3. С. 39-46.

4. Енкен В.Б. Роль генотипа в экспериментальном мутагенезе. Экспериментальный мутагенез у с.-х. растений и его использование в селекции. 1966. С. 23-24.

5. Батыгин Н.Ф. Селекционный процесс и индуцированный мутагенез. Радиационный мутагенез и его роль в эволюции и селекции. Москва: Наука, 1987. С. 16-18.

6. Позолотина В.Н. Отдаленные последствия действия радиации на растения. Москва: Академкнига, 2003. 243 с.

7. Баштан Н.О., Крутько Р.В., Сергієнко О.В., Кондратенко С.І., Івченко Т.В. Вплив різних доз $\gamma$-опромінення на ріст і розвиток рослин кавуна. Овочівництво $i$ баштанництво. 2017. № 63. C. 26-35.

8. Сергієнко О.В., Крутько Р.В., Баштан Н.О. Особливості прояву господарсько-цінних ознак за різних доз обробки насіння $\gamma$ - опромінюванням. Овочівництво і баштанництво: історичні аспекти, сучасний стан, проблеми і перспективи розвитку: матеріали III міжнародної науково-практичної конференції. Крути, 2017. Т. 1. С. 238-244.

9. Лимар А.О. та ін. Методика селекційного процесу та проведення польових дослідів 3 баштанними культурами: методичні рекомендації. Київ: Аграрна наука, 2001. 132 с. 


\title{
References
}

1. Teodoradze SG. Creation of new intensive varieties of agricultural crops by radiation breeding. Selskokhozyaystvennaya Biologiya. 1983; 10: 62-67.

2. Morhun VV. Spontaneous and induced mutational variability and its use in plant breeding. Genetics and breeding in Ukraine at the turn of the millennium. 2001; 2: 144-174.

3. Kravchenko VA, Korniienko SI, Kondratenko SI, Serhiienko OV, Horova TK, Samovol OP, Saiko OYu. Effective methods and ways of breeding and seed production of vegetables and melons. Visnyk Ahrarnoi Nauky. 2017; 3: 39-46.

4. Yenken VB. The role of genotype in experimental mutagenesis. Experimental mutagenesis in agricultural plants and its use in breeding. 1966; 23-24.

5. Batygin NF. Breeding process and induced mutagenesis. Radiation mutagenesis and its role in evolution and breeding. Moscow: Nauka, 1987; 16-18.

6. Pozolotina VN. Long-term effects of radiation on plants. Moscow: Akademkniga, 2003. 243 p.

7. Bashtan NO, Krutko RV, Serhiienko OV, Kondratenko SI, Ivchenko TV. Influence of different doses of $\gamma$-irradiation on the growth and development of watermelon plants. Ovochivnytstvo i Bashtannytstvo. 2017; 63: 26-35.

8. Serhiienko OV, Krutko RV, Bashtan NO. Peculiarities of expression of economically valuable traits after $\gamma$-irradiation of seeds at different doses. Vegetable and Gourd Growing: Historical Aspects, Current State, Problems and Prospects of Development: Abstracts of the $3^{\text {rd }}$ International Scientific and Practical Conference. Kruty, 2017; 1: 238-244.

9. Lymar AA et al. Methods of breeding process and field experiments on gourds: guidelines. Kyiv: Ahrarna Nauka, 2001. 132 p.

\section{РОЗШИРЕННЯ СПЕКТРУ ГЕНОТИПОВОЇ МІНЛИВОСТІ КАВУНА МЕТОДОМ ФІЗИЧНОГО МУТАГЕНЕЗУ}

\author{
Шабетя $^{1}$ O.М., Сергієнко ${ }^{2}$ O.В., Могильная ${ }^{2}$ O.М., Кондратенко ${ }^{2}$ C.I., Моргун ${ }^{3}$ Л.В. \\ ${ }^{1}$ Інститут рослинництва імені В.Я. Ю'рєва НААН, Україна \\ ${ }^{2}$ Інститут овочівництва і баштанництва НААН, Україна \\ ${ }^{3}$ Апарат Президії Національної академії аграрних наук України
}

Мета дослідження. Проведено дослідження з розширення спектру генотипової мінливості кавуна шляхом індукованого мутагенезу на 18 перспективних генотипів кавуна.

Матеріали і методи. Повітряно-сухе насіння опромінювали за допомогою $\gamma$-установки закритого типу «Дослідник» джерелом 60 Со на кафедрі молекулярної та медичної біофізики факультету радіофізики, біомедичної електроніки та комп’ютерних систем Харківського національного університету ім. В. Н. Каразіна МОН України.

Обговорення результатів. За кожною 3 найбільш інформаційних селекційних ознак проведено статистичний аналіз закономірностей та рівня їх прояву за варіантами обробки мутагеним фактором (різних доз опромінення 150 Гр, 200 Гр та 250 Гр) за кожним із 18 окремих генотипів. Визначено закономірності впливу окремих доз опромінення на ріст $\mathrm{i}$ розвиток рослин як за окремими генотипами так і за їх сукупністю. Встановлено, що на більшість генотипів дози $\gamma$-опромінення мають пригнічуючий вплив (пізньостиглість, довго- та короткостебельність, збільшення номеру закладання 1 жіночої квітки, подовження складових вегетаційного періоду), але визначено ряд генотипів та їх груп (кластерів) прояв ознак у яких мав протилежну (виключну) дію. Визначено джерела господарсько-цінних ознак, а також ефективні дози $\gamma$-опромінення за генотипами (кластерами) так: для селекції на урожайність - 4 генотипи 4 кластеру при $\gamma$-опроміненні 250 Гр; на товарність: 2 генотипи 3 кластеру за $\gamma$-опромінювання $150-250$ Гр; на крупноплідність: 3 генотипи 3 кластеру за $\gamma$-опромінювання 150, 200 та 250 Гр; на пізньостиглість: 1 генотип 5 кластеру за $\gamma$-опромінювання 150,200 та 250 Гр; на ранньостиглість: 2 генотипи 3 кластеру за $\gamma$-опромінювання 200 та 250 Гр та 5 генотипів 5 
кластеру за $\gamma$-опромінювання 150, 200 Гр; на довгостебельність: 3 генотипи 3 кластеру за $\gamma$-опромінювання 200 та 250 Гр та 7 генотипів 5 кластеру за $\gamma$-опромінювання 150, 200, а особливо 250 Гр; на короткостебельність: 1 генотип 1 кластеру за $\gamma$-опромінювання 150, 200 та 250 Гр.

Ключові слова: кавун; генотип; ознака; індукований мутагенез; $\gamma$-опромінювання; дози үопромінення; кластер; закономірності.

\section{РАСШИРЕНИЕ СПЕКТРА ГЕНОТИПИЧЕСКОЙ ИЗМЕНЧИВОСТИ АРБУЗА МЕТОДОМ ФИЗИЧЕСКОГО МУТАГЕНЕЗА}

Шабетя ${ }^{1}$ О.Н., Сергиенко ${ }^{2}$ О.В., Могильная ${ }^{2}$ Е.Н., Кондратенко ${ }^{2}$ С.И., Моргун ${ }^{3}$ Л.В.

${ }^{1}$ Институт растениеводства имени В.Я. Юрьева НААН

${ }^{2}$ Институт овощеводства и бахчеводства, НААН

${ }^{3}$ Аппарат Президиума Национальной академии аграрных наук Украины

Цель исследования. Проведены исследования по расширению спектра генотипической изменчивости арбуза путем индуцированного мутагенеза на 18 перспективных генотипах арбуза.

Материалы и методы. Воздушно-сухие семена облучали при помощи $\gamma$-установки закрытого типа «Исследователь» источником 60 Со на кафедре молекулярной и медицинской биофизики факультета радиофизики, биомедицинской электроники та компьютерных систем Харьковского национального университета им. В. Н. Каразина МОН Украины.

Обсуждение результатов. По каждому из наиболее информационных селекционных признаков проведен статистический анализ закономерностей и уровня их проявления по вариантам обработки мутагенным фактором (разных доз облучения 150 Гр, 200 Гр та 250 Гр) по каждому из 18 разных генотипов. Выявлены закономерности влияния отдельных доз облучения на рост и развитие растений, как по отдельным генотипам так и их совокупности. Установлено, что у большинства генотипов дозы $\gamma$-облучения имеют угнетающее действие (позднеспелость, длинно- и короткостебельность, увеличение порядка закладки 1 женского цветка, удлинение составляющих вегетационного периода), однако выделен ряд генотипов и их групп (кластеров) проявление признаков у которых имело противоположенное (исключительное) действие. Выделены источники хозяйственно - ценных признаков, а также эффективные дозы $\gamma$-облучения по генотипам (кластерам) это: для селекции на урожайность - 4 генотипа 4 кластера при $\gamma$-облучении 250 Гр; на товарность: 2 генотипа 3 кластера при $\gamma$ - облучении $150-250$ Гр; на крупноплодность: 3 генотипа 3 кластера при $\gamma$ - облучении 150, 200 и 250 Гр; на позднеспелость: 1 генотип 5 кластера при $\gamma$ - облучении 150, 200 и 250 Гр; на раннеспелость: 2 генотипа 3 кластера при $\gamma$ - облучении 200 и 250 Гр и 5 генотипов 5 кластера при $\gamma$ - облучении 150, 200 Гр; на длинностебельность: 3 генотипа 3 кластера при $\gamma$ - облучении 200 та 250 Гр и 7 генотипов 5 кластера при $\gamma$ - облучении 150, 200, и особенно 250 Гр; на короткостебельность: 1 генотип 1 кластера при $\gamma$ - облучении 150, 200 та 250 Гр.

Ключевые слова: арбуз; генотип; признак; индуцированный мутагенез; $\gamma$ - облучение; дозы $\gamma$ облучения; кластер; закономерности. 


\section{EXPANSION OF THE GENOTYPIC VARIABILITY IN WATERMELON BY PHYSICAL MUTAGENESIS}

Shabetia $^{1}$ O.N., Serhienko ${ }^{2}$ O.V., Mohilnaia ${ }^{2}$ E.N., Kondratenko ${ }^{2}$ S.I., Morhun ${ }^{3}$ L.V. .

${ }^{1}$ Plant Production Institute named V.Ya Yuriev of NAAS, Ukraine

${ }^{2}$ Institute of Vegetable and Melon Growing of National Academy of Agrarian Sciences of Ukraine, Ukraine

${ }^{3}$ Presidium of the National Academy of Agrarian Sciences of Ukraine, Ukraina

Purpose. Studies have been conducted on 18 promising watermelon genotypes to expand the genotypic variability of watermelon by induced mutagenesis.

Materials and methods. Air-dried seeds were irradiated with a closed ${ }^{60} \mathrm{Co} \gamma$-source «Doslidnyk» (Department of Molecular and Medical Biophysics, Faculty of Radiophysics, Biomedical Electronics and Computer Systems, V.N. Karazin Kharkiv National University of MES of Ukraine).

Results and discussion. Each of the most informative breeding traits was statistically analyzed for their expression patterns and levels by variants of mutagenic treatment (different doses - $150 \mathrm{~Gy}$, $200 \mathrm{~Gy}$, and $250 \mathrm{~Gy}$ ) in each of the 18 genotypes. The patterns of influence of the irradiation doses on plant growth and development have been determined, both in individual genotypes and for the whole sample. It has been found that $\gamma$-irradiation had a depressing effect in the majority of genotypes (late maturation, long or short stems, altered order of the $1^{\text {st }}$ female flower formation, extended phases of the growing period). Genotypes and their groups (clusters), in which expression of traits is opposite (alternative), have been identified. Sources of economically valuable traits have been identified, and the following effective doses of $\gamma$ irradiation have been established for genotypes (clusters): 4 genotypes of cluster $4 \gamma$-irradiated at $250 \mathrm{~Gy}$ - in breeding for yield capacity; 2 genotypes of cluster $3 \gamma$-irradiated at $150-250 \mathrm{~Gy}-$ in breeding for marketability; 3 genotypes of clusters $3 \gamma$-irradiated at 150, 200 or $250 \mathrm{~Gy}-$ in breeding for large fruits: 1 genotype of cluster $5 \gamma$-irradiated at 150, 200 or $250 \mathrm{~Gy}$ - in breeding for late maturation; 2 genotypes of cluster $3 \gamma$-irradiated at 200 or 250 Gy and 5 genotypes of cluster $5 \gamma$-irradiated at 150 or $200 \mathrm{~Gy}$ - in breeding for early maturation; 3 genotypes of cluster 3 $\gamma$-irradiated at 200 or 250 Gy and 7 genotypes of cluster $5 \gamma$-irradiated at 150, 200 and especially $250 \mathrm{~Gy}$ - in breeding for long stems; and 1 genotype of cluster $1 \gamma$-irradiated at 150, 200 or 250 Gy - in breeding for short stems.

Key words: watermelon; genotype; trait; induced mutagenesis; $\gamma$-irradiation; doses of $\gamma$ irradiation; cluster; patterns. 